\title{
An Investigation into the Business Social Responsibility of Micro Enterprises in South Africa
}

\author{
Annikie Morongwa Ramasobana \\ Department of Business Management, Turfloop Campus, \\ University of Limpopo, Limpopo Province, South Africa \\ Email:mppaile@webmail.co.za \\ Olawale Fatoki \\ Department of Business Management, Turfloop Campus, \\ University of Limpopo, Limpopo Province, South Africa \\ Email: Olawale.fatoki@ul.ac.za
}

Doi:10.5901/mjss.2014.v5n3p283

\begin{abstract}
The purpose of this study was to examine the business social responsibility of micro enterprises in Mankweng, Limpopo Province, South Africa. The study had three objectives. (1) to investigate the attitudes of micro enterprises towards business social responsibility (2) to investigate the practice of business social responsibility by micro enterprises and (3) to analyse the barriers to the practice of business social responsibility by micro enterprises. Data was collected through the use of selfadministered questionnaires in a survey. Univariate statistics was used for data analysis. The results indicated that micro enterprises have a positive attitude towards business social responsibility. In addition, the results indicated that the majority of micro enterprises are weak in community and environmental responsibility. Cost and limited information are the major constraints to the practice of BSR by micro enterprises. Recommendations to improve the practice of business social responsibility by micro enterprises are suggested.
\end{abstract}

Keywords: Business social responsibility; micro enterprises; Mankweng; South Africa

\section{Introduction}

Small medium and micro enterprises (SMMEs) are seen as playing an important role in the economies of many countries including South Africa. According to the World Bank (2008), the three major economic development challenges facing South Africa are high levels of poverty, income inequality and unemployment. One of the ways of meeting these challenges is ensuring the development of SMMEs. Thus, SMMEs are keys to poverty alleviation, income equality, employment and sustainable economic growth in South Africa (FinMark Trust, 2006). Micro, very small and small enterprises contribute between 27-34\% of the Gross Domestic Product and 72\% of all jobs in South Africa (Department of Trade and Industry 2008).

According to the Parliament of the Republic of South Africa (2005), a micro-enterprise is a business with (1) total full-time equivalent of paid employees less than 5, (2) total annual turnover of less than R150,000 and (3) total gross fixed assets value(fixed property excluded) of less than R100,000. Micro-enterprises comprise the smallest (by size) of the small business sector. Jeppensen et al. (2012) point out that micro enterprises have a considerable role and impact when it comes to social issues (i.e. income, working conditions and the working environment. and environmental issues (i.e. pollution and sustainable development). Samujh (2011) points out that despite the importance of micro enterprises, their entrepreneurial role in building communities has not often been given adequate consideration. Micro enterprises tend to be overlooked, intentionally or unintentionally in small business research. The lack of participation by micro enterprises in small business research places them in a category of the "silent (or silenced) majority".

Longo et al. (2005) and Turyakira et al. (2012) find that corporate/business social responsibility positively impacts on firm performance. Adeniran and Johnston (2012) note that the failure rate of SMMEs in South Africa is between 70\% and $80 \%$. The high failure rate casts doubt on the sector's ability to create sustainable employment and reduce poverty. Therefore, the survival of SMMEs is of vital importance in South Africa. Turyakira et al. (2012) point out that the 
outcomes of business social responsibility (BSR) activities can help to improve the survival rate of SMMEs, and may offer great opportunities for business competitiveness, locally and globally. BSR is one of the important ways in which a business can distinguish itself from its competitors. Businesses have to give back to the society and the environment within which they operate. A powerful tool like BSR not only enhances the brand image and reputation of the business but also leads to improvement in sales and customer loyalty, and increased ability to attract and retain employees (Sharma and Devi 2009). In order to be successful in the business environment, SMMEs have to include BSR in their strategic decisions (Mankelow and Quazi 2007). This suggests that the adoption of BSR can help to reduce the high failure rate of SMMEs in South Africa.

A thorough review of the literature on corporate/business social responsibility in South Africa (Jeppesen et al. 2012; Turyakira et al. 2012; and Rootman and Zeka, 2013) revealed that no study has empirically investigated the attitude, practice and barriers to BSR by micro enterprises in a rural environment in South Africa.

\section{Objectives}

SMMEs are very important to the reduction of unemployment, poverty and income inequality in South Africa. However, the failure rate of SMMEs is very high in South Africa. The practice of BSR positively impacts on firm performance and survival. The objectives of the research are:

- To assess the attitudes of micro enterprises towards business social responsibility.

- To investigate the practice of business social responsibility by micro enterprises.

- To analyse barriers to the practice of business social responsibility by micro enterprises.

\section{Literature Review}

\subsection{Definition of BSR}

According to Surroca et al. (2010), corporate/business social responsibility has been dissected into many components by many authors, each with a different agenda. These include terms such as corporate responsibility, corporate citizenship, sustainability, and corporate social performance. The European Union Commission (2011) is of opinion that business social responsibility is a concept whereby companies integrate social and environmental concerns in their business operations in the interaction with their stakeholders on a voluntary basis. Cochius (2006) points out that BSR implies that "a business should not spoil the neighbourhood it operates in, and they should also assume a voluntary contribution to solving neighbourhood problems". Dinakar (2004) argues that business social responsibility is linked with the concept of Triple Bottom Line Reporting (TBL) which is used as a framework for measuring an organisation's performance against economic, social and environmental parameters. Possenti (2012) points out that that BSR is a process that is concerned with the ethical treatment of the stakeholders of a company or institution. Stakeholders include internal and external stakeholders.

Siwar and Md-harizan (2004:3) posit that BSR is about managing change in a company level, in a socially responsible manner which can be viewed in two dimensions.

- Internally: socially responsible practices that mainly deal with employees and is related to aspects such as investing in human health and being environmentally responsible.

- Externally: BSR involves a wide range of stakeholders such as customers, business partners, public authorities and non-governmental organisations representing local communities as well as the environment.

According to the King Report on Corporate Governance (2009) BSR involves "a well-managed company that is aware of and responds to social issues, placing a high priority on ethical standards. BSR can also be a voluntary way of organisations to contribute to a better society and a cleaner environment.

\subsection{Theoretical framework of BSR}

Friedman (1962) in the stockholder theory states that the business of business is about maximising stockholder wealth, not "promoting desirable 'social' ends". Friedman (1962) furthermore states that there is one and only one social responsibility of business: to use its resources to engage in activities designed to increase its profits so long as it stays within the rules of the game. The stakeholder theory of corporate/business social responsibility by Freeman (1984) views the corporation as a set of interrelated, explicit or implicit connections between individuals or groups. Stakeholders 
include anyone who can affect or is affected by the actions of the firm. This approach is based on a notion that, firms are responsible for addressing the interests of different stakeholders and not only focuses on the owners' interests. The stakeholder theory covers all the stakeholders and also holds that making profit for the firm and its shareholders, as well as fulfilling other duties to other groups associated with the firm are the essence for which a firm exists (Freeman, 2004).

Carroll (1991) designed a pyramid of corporate social responsibility which identifies a spectrum of obligations that companies have towards the society in which business operations are conducted. The Carroll's pyramid of corporate social responsibility identifies the major obligations which business firms have towards the society in which it conducts its business activities. The framework consists of four steps. The four steps are the economic, legal, ethical and philanthropic behaviour. The main emphasis of the framework rests on the economic aspect of the organization but also argues on other aspects such as legal, ethical and philanthropic behaviour. The economic behaviour is mainly concerned with the fact that firms should be profitable to survive in the industry. The legal aspects focus on the firms' ability to work within the boundaries of laws and national policies. Ethical responsibilities demand that the firm act fairly, justly and operate morally. Philanthropic responsibility obliges companies to contribute financial and other resources of the welfare and betterment of society and community.

\subsection{Business social responsibility and SMMEs}

BSR is seen as an important strategy to invigorate SMMEs operations and competitiveness (Turyakira et al. 2011). Given the importance of SMMEs for the process of economic development and their social and environmental impact, the adoption of socially responsible practices in the context of small business is of significant value (Possenti, 2012). In the SMME context, practising BSR often originates from an owner or long-term employee's personal values or when there is an expressed appetite for sustainable operations and products among customers and business partners (Princic, 2003). Dincer and Dincer (2006:) find that SMME executives are generally influenced by personal feelings, friends and religion when making decisions related to BSR. Cochius (2006) argues that long-run self-interest is one of the most prevalent reasons to practice BSR. Business needs to provide a variety of social goods in order to remain profitable in the long run.

Princic (2003) finds that the environmental and social responsibilities of SMMEs are significantly and positively related to their financial performance. Hossain et al. (2013) find that BSR improves the financial performance through cost reduction, efficient employee and more sales. Longo et al. (2005) and Branco and Rodrigues, 2006) reveal that BSR positively impact on the growth of SMMEs. The practice of BSR brings many benefits to a business. The benefits include improvement of image, reputation, goodwill, employee motivation and positive approach from stakeholders BSR improves business trust and understanding between SMMEs and its customers (Hossain et al. 2013). BSR is a tool for attracting talented and diverse workforce. Organizations that ensure the interests of their workforce by offering excellent working environments will achieve superior performance in terms of quality and therefore, experience superior levels of productivity (Brown et al. 2009).

Nejati and Amran (2009) find that most SMMEs do not practise BSR mainly because they feel that there are no benefits from it. Razaq (2013) find that lack of knowledge, high costs and no immediate benefit to business are the main barriers for micro enterprises to practise BSR. Bay (2012) reveal that the barriers to the practice of BSR are: the little understanding of BSR and the lack of technology, expertise, training and investment necessary to undertake BSR. Sweeney (2007) notes that the main barriers to the application of BSR by SMMEs are the high cost, lack of knowledge and that BSR is time consuming and complicated. Siwar and Md-Harizan (2004) conclude that the barriers to the adoption of BSR by SMMEs are lack of time, motivation, insufficient resources and capabilities and also the perception that community involvement is not related to business. Possenti (2012) agrees that the scarcity of assets such as stock of technology, environmental infrastructure and environmentally friendly materials, credit, financial inputs, incentives, information and training are the barriers for the adoption of BSR by SMMEs

\section{Research Methodology}

This study used the quantitative research methodology. This study used a combination of exploratory and descriptive research. Data was collected through the use of self-administered questionnaire in a survey. The study focused on micro enterprises in Mankweng, Limpopo province of South Africa. There is no sampling frame of micro enterprises in the study area, thus convenience sampling method was used. The use of convenience sampling is consistent with previous empirical studies on SMMEs in South Africa such as Farrington and Machaba-Hove (2011) and Arko-Achemfuor (2012). A pilot study was conducted on the survey instrument used in this research with 15 owners of micro enterprises to ensure 
face and content validity. The number of employees was used to determine micro enterprises. The questions to measure the attitudes toward BSR were adapted from the Attitudes Toward Corporate Social Responsibility Questionnaire by Abdul and Ibrahim (2002). The five-point Likert Scale ranging from 1 strongly disagree, 2 disagree, 3 not sure, 4 agree and 5 strongly agree was used to measure the attitudes toward BSR. Questions on the practice of BSR and the barriers to the adoption of BSR by micro enterprises were adapted from previous empirical studies such as Longo et al. (2005) and Amran and Nejati (2011). Ethical considerations were followed during the data collection process. Owners were assured of confidentiality with regard to the data collected. Data analysis was done through the use of descriptive statistics. The study focused on the owners of the enterprise.

\section{Research Results}

\subsection{Response rate and demographics of the respondents}

One hundred and thirty six questionnaires were distributed and 61 were returned. The response rate was $45 \%$. Most of the respondents are between the age of 21 and 40 and have matric or post matric qualifications. 33 respondents are in the retail business and 28 respondents are in the service business. 36 respondents were male and 26 female. 55 respondents were sole proprietors, 4 partnerships and two companies. 32 respondents were in the 1-5 age bracket, 28 in the 6-10 age bracket and 1 above ten years. 45 respondents have at least one employee and 16 no employee.

\subsection{Attitudes toward business social responsibility}

Table 1: Descriptive Statistics on the attitudes of micro enterprises toward BSR

\begin{tabular}{|l|c|c|}
\hline \multicolumn{1}{|c|}{ Variables } & $\begin{array}{c}\text { Mean } \\
\text { scores }\end{array}$ & $\begin{array}{c}\text { Standard } \\
\text { deviation }\end{array}$ \\
\hline $\begin{array}{l}\text { 1. Involvement by business in improving its community's quality of life will also improve long run } \\
\text { profitability. }\end{array}$ & 4.09 & 0.840 \\
\hline $\begin{array}{l}\text { 2. A business that wishes to capture a favourable public image will have to show that it is socially } \\
\text { responsible. }\end{array}$ & 4.07 & 0.856 \\
\hline $\begin{array}{l}\text { 3. The idea of socially responsibility is needed to balance company's power and discourage } \\
\text { irresponsible behaviour. }\end{array}$ & 4.19 & 0.852 \\
\hline $\begin{array}{l}\text { 4. Firms are social institutions and as such much live up to society's standards. } \\
\text { 5. Efficient production of goods and services is no longer the only thing society expects from } \\
\text { businesses. }\end{array}$ & 4.51 & 0.806 \\
\hline $\begin{array}{l}\text { 6. If business is more socially responsible, it will discourage additional regulation of the economic } \\
\text { system by the government. }\end{array}$ & 4.07 & 0.851 \\
\hline $\begin{array}{l}\text { 7.A business that ignores corporate social responsibility can obtain a competitive advantage than a } \\
\text { company that does not }\end{array}$ & 2.63 & 0.828 \\
\hline
\end{tabular}

The results of the attitudes toward BSR as depicted by table 1 show that micro enterprises have a good attitude towards BSR. Most of the respondents agree with the notion that involvement by business in improving its community's quality of life will also improve long run profitability. In addition, most of the respondents disagree with the notion that business that ignores corporate social responsibility can obtain a competitive advantage than a company that does not.

\subsection{The practice of $B S R$}

Table 2: Type of BSR practiced

\begin{tabular}{|l|c|}
\hline \multicolumn{1}{|c|}{ Types of BSR } & Percentage of respondents \\
\hline Employees & \\
\hline Provide external training for employees & $2 \%$ \\
\hline Have facilities at work that provide for the health of the worker (first aid box) & $23 \%$ \\
\hline Have facilities at work that provide for the safety of the worker (firefighting equipment) & $56 \%$ \\
\hline Do not discriminate in the employment of workers on the basis of sex, race and disability & $88 \%$ \\
\hline
\end{tabular}




\begin{tabular}{|l|c|}
\hline Suppliers & \\
\hline Pay suppliers as agreed & $65 \%$ \\
\hline Customers & $92 \%$ \\
\hline Strive to maintain good product or service quality & $68 \%$ \\
\hline Allow customers to return defective goods for a new one or a refund & \\
\hline Community and environment & $71 \%$ \\
\hline Have the preference of employing people from the community & $5 \% \%$ \\
\hline Involved in sponsorship of any kind & $31 \% \%$ \\
\hline Donations & $12 \%$ \\
\hline Support sports, cultural or social activities & $5 \%$ \\
\hline Involved in the recycling of waste products & \\
\hline
\end{tabular}

The study focused on the four areas of BSR which are the employees, the customers, the suppliers and the community. The results indicate that most respondents do not provide external training for employees, have facilities at work that provide for the health of the worker (first aid box). This can negatively impact on the wellness of employees. However, the majority of the respondents do not discriminate in the employment of workers on the basis of sex, race and disability.

The majority of the respondents pay their suppliers as agreed. This indicates a high level of responsibility to suppliers. In addition, the majority of the respondents strive to maintain good product or service quality and allow customers to return defective goods for a new one or a refund (respondents in retail). This indicates a high level of customer responsibility.

The majority of the respondents prefer to employ workers from the community. However, the majority of the respondents are not involved in sponsorship, donations, and support for sports and recycling. This indicates a low level of community and environmental responsibility.

\subsection{Barriers to the practice of BSR by micro enterprises}

\subsubsection{Barriers to the application of BSR}

Table 3: barriers to the application of BSR

\begin{tabular}{|l|c|c|}
\hline \multicolumn{1}{|c|}{ Barriers } & Mean & Standard deviation \\
\hline It is costly & 4.67 & 0.479 \\
\hline No perceived benefits & 4.17 & 0.262 \\
\hline Limited information about BSR & 4.15 & 0.907 \\
\hline Not interested & 2.17 & 0.898 \\
\hline Limited time & 2.02 & 0.925 \\
\hline
\end{tabular}

Table 3 depicts the barriers to the application of BSR by micro enterprises. The means (on a five-point Likert scale) indicate that most micro enterprises perceive cost (mean of 4.67), no perceived benefits (mean of 4.17) and limited information about BSR (4.15) as the main barriers to the practice of BSR.

\section{Conclusions}

The research objectives for the study were: to assess the attitudes of micro enterprises towards business social responsibility; to investigate the practice of business social responsibility by micro enterprises; and to analyse barriers to the practice of business social responsibility by micro enterprises. The results indicate a good attitude towards BSR by the owners of micro enterprises. The results indicate that for employee responsibility, the majority of the respondents do not provide external training for employees, however, the majority of the respondents do not discriminate in the employment of workers on the basis of sex, race and disability. The results furthermore indicate a high level of supplier and customer responsibility but a rather low level of community and environmental responsibility. The findings of this study are consistent with the results of suimilar empirical studies on BSR such as Longo et al. (2005) and Amran and Nejati (2011). 


\section{Recommendations}

Micro enterprises should design a strategic plan that will incorporate the specific commitments and expected behaviours in relation to their stakeholders. The will serve as a guideline on how they will address environmental responsibility, customer responsibility, employee responsibility and supplier responsibility. The owners of micro enterprises should establish specific, measurable and attainable goals for ensure and improve business social responsibility. Micro enterprises must also focus on creating a vision, mission and statement of values for the firm. The vision should explicitly include BSR as one of its core elements. To ensure the support from employees, management should include them in the process of developing the vision and values. Micro enterprises need to be made aware of business social responsibility. Bigger companies as part of their social responsibility can educate micro businesses about BSR. Government agencies should promote and encourage micro enterprises to engage in BSR activities as well as organising training for micro enterprises to better understand BSR. Micro enterprises also have the responsibility to seek information on ethical business practices and create time to engage in those practices.

\section{References}

Adeniran, T. V, \& Johnston, K. A. (2012). Investigating the dynamic capabilities and competitive advantage of South African SMEs. African Journal of Business Management, 6(11): 4088-4099.

Arko-Achemfour. A. (2012). Financing SMMEs in rural South Africa: An exploratory study of stokvels in the Nailed Local municipality, North West province. Sociology Anthropology, 3(2):127-133

Bay, Ray, (2012), Implications for SMEs in developing countries. [Online]. Available: www.unido.org/index.php/sabr/article/download 17635/66809. (May 16, 2013).

Branco, M.C. \& Rodrigues, L.L. (2006). Communication of corporate social responsibility by Portuguese banks: A legitimacy theory perspective, Corporate Communications: An International Journal, 11(3):232-248.

Carroll, A. (1991). The four faces of corporate citizen- ship. Business and Society Review, 100(1): 1-7.

Cochius, T. (2006). Corporate Social Responsibility in Dutch SMEs. Journal of Corporate Social Responsibility,5(3):17-33.

Department of Trade and Industry 2008. Annual Review of small businesses in South Africa. [Online] Available: http://www.dti.gov.za/sme (July 15, 2013)

Dinakar, Peri, (2004), Corporate social responsibility. Asocio-paper. [Online] Available. www.asocio.org/policy/Corporate\%Social \%20Responsibility.pdf. [June 7, 2013].

Dincer, B., and Dincer, C. (2006). CSR decisions: A dilemma for SME executive. Social Responsibility Journal. 9(2): 177-187.

European Union Commission, (2011). Small and Medium-sized Enterprises. [Online]. Available: http://ec.europa.eu/enterprise /policies/sme/facts-figures-analysis/ sme-definition/in-dex en.htm.[May 2, 2013].

Farrington, Shelley, and Matchaba-Hove, Tony, (2011.. The Influence of Entrepreneurial Orientation on Small Business Success. [Online] Available: www.saims2011. ukzn.ac.za/Libraries/Final_Programme/Final_SAIMS_Programme_2011.sflb.ashx> (May 16, 2013].

FinMark Trust (2006). Fin scope small business survey report. [Online]. Available: http://www.finmark trust.org.za. [April 20, 2013].

Freeman, R. (1984). Strategic management: A Stakeholder Approach. (1st ed.). Boston: Pitman.

Friedman, Milton. (1970). The Social Responsibility of a Business is to Increase its Profit. [Online]. Available: http://www.colo rado.edu.studentgroups/libertarians/issues/friedmen- soc-responsibility. [April 28. 2013).

Hossain, T.B., Siwar, C., Jani, M.F.M.\& Bhuiyan, A.B. 2013. Corporate Social Responsibility (CSR) for Global Market Access: A Malaysian Case Study on Small and Medium Enterprises (SMEs). Research Journal of Applied Sciences, Engineering and Technology, 5(1): 60-65.

Jeppesen, Soeren., Kothuis, Bas, and Ngoc Trans Angie, (2012), Corporate Social Responsibility and Competitiveness for SMEs in Developing Countries: South Africa and Vietnam. [Online] Available: http://www.afd.fr/C80BD74C-6628-40C5-907D6C6F7475BE16/FinalDownload/Download pdf (May 15, 2013)

King report (2009), King report on corporate governance South Africa. Institute of Directors in South Africa. [Online]. Available. http://www.iodsa.co.za/productservisec/KingllIReportPapersGuidelines/King Reporton Corporate GovernanceinSA.aspx. [April 25, 2013].

Levy, David, Brown, Halina, \& De jong, Martin, (2009), The contested politics of corporate governance: the case of global reporting initiative, business and society. [Online]. Available: www.faculty.umb.edu/david_levy/webcv.html. [May 4, 2013]

Longo, M., Mura, M. and Banoli. (2005). Corporate social responsibility and corporate performance: the case of Italian SMEs. Corporate governance, 5(4):28-42.

Mankelow, G. and Quazi, A. (2007). Factors affecting SMEs motivations for corporate social responsibility. Jounal of Business Ethics, 6(7): 2367-2374

Nejati, M. and Amran, A. (2009). Corporate social responsibility and SMEs: exploratory study on motivations from a Malaysian perspective. Business Strategy Series, 10(5):259- 265.

Parliament of the Republic of South Africa. (2005). The white paper on national strategy for development. www.info.gov.za/white 
paper/1995/smallbus.htmNational Small Business Act (1996). Definition of Small Businesses. [Online]. Available: $<$ www.smesurvey.co.za/research-current.htm[May 30, 2013)

Possenti, S. (2012). Exploring the Link between CSR and SMEs in Developing Countries: the Case of Somalia. Journal of Business Management, 6(5):155-178.

Prinsic, Lisa. (2003), Engaging small business in corporate social responsibility. (Online) Available: http://info.worldbank.org /etools/docs/library/114189/Engaging\%20SME\%20in\%20CSR\%202003.pdf (May 19, 2013)

Rootman, C. and Zeka, B. (2013). The brand image and performance of small and medium enterprises: How can CSR activities help? Acta commerci, 13(1):1- 9.

Samujh, Helen, (2011), The role of small and medium business practises in providing support to small and medium sized enterprises. [Online]. Available: www.waikato.ac.nz/php/research.php?mode=show \&author-rhsamuj. [June 14, 2013].

Sharma, S., Sharma, J. and Devi, A. (2009). Corporate social responsibility: The key role of human resource management. Business Intelligence Journal, 2(1):205-213.

Siwar, Chamhuri. and Md-Harizan, Siti, (2004), Corporate social responsibility practices among businesses organisations- in Malaysia. [Online]. Available: www.wbiconpro.com/242-Siwar,C\%0\&\%20Harizan,S.pdf. [February 28, 2013].

Surroca, J, Tribo, J.A, \& Waddock, S. (2010). Corporate responsibility and financial performance : the role of intangible resources. Strategic Management Journal, 31(5): 463-490.

Sweeney, L. (2007) Corporate social responsibility in Ireland: barriers and opportunities experienced by SMEs when undertaking CSR, Corporate Governance, 7(4): 516 - 523

Turyakira, P.K, Venter, E and Smith E. (2012). Corporate social responsibility: A hypothesised model. African Journal of Business Ethics, 6(2):106-119.

World Bank. (2008), South African Country Brief. [Online]. Available: http:/ /siteresource.worldbank. Org/GILDSOUTHAFRICA/ insolvency\%20law. [April 12, 2013). 